\title{
Nickel-cobalt bimetallic anode catalysts for direct urea fuel cell
}

\section{CONFERENCE PROCEEDINGS}

APEnergy2014

\section{SUBJECT AREAS:} ELECTROCHEMISTRY

CATALYSIS

Received

3 February 2014

Accepted

27 June 2014

Published

29 August 2014

Correspondence and requests for materials should be addressed to

Z.C.W. (wuzc@zju. edu.cn)

\author{
Wei Xu, Huimin Zhang, Gang Li \& Zucheng Wu
}

Department of Environmental Engineering, Laboratory of Electrochemistry and Energy Storage; State Key laboratory of Clean Energy Utilization, Zhejiang University, Hangzhou 310058 , P. R. China.

Nickel is an ideal non-noble metal anode catalyst for direct urea fuel cell (DUFC) due to its high activity. However, there exists a large overpotential toward urea electrooxidation. Herein, $\mathrm{NiCo} / \mathrm{C}$ bimetallic nanoparticles were prepared with various Co contents $(0,10,20,30$ and $40 \mathrm{wt} \%)$ to improve the activity. The best Co ratio was $10 \%$ in the aspect of cell performance, with a maximum power density of $1.57 \mathrm{~mW} \mathrm{~cm}-2$ when $0.33 \mathrm{M}$ urea was used as fuel, $\mathrm{O}_{2}$ as oxidant at $60^{\circ} \mathrm{C}$. The effects of temperature and urea concentration on DUFC performance were investigated. Besides, direct urine fuel cell reaches a maximum power density of $0.19 \mathrm{~mW} \mathrm{~cm}^{-2}$ with an open circuit voltage of $0.38 \mathrm{~V}$ at $60^{\circ} \mathrm{C}$.

U rea, widely used as fertilizer, can be produced via series chemical processes by using $\mathrm{H}_{2}, \mathrm{~N}_{2}$ and $\mathrm{CO}_{2}{ }^{1,2}$. It is an ideal $\mathrm{H}_{2}$ and $\mathrm{CO}_{2}$ storage medium due to its high energy density $\left(16.9 \mathrm{MJ} \mathrm{L}^{-1}, 10.1\right.$ weight percent of $\mathrm{H}_{2}$ ), safety and convenience of transportation ${ }^{3,4}$. Figure 1 demonstrates that urea functions as an important intermediate in a nitrogen and carbon recycle system. $\mathrm{N}_{2}$ and $\mathrm{CO}_{2}$ can be achieved from air, and $\mathrm{H}_{2}$ can be produced from water. $\mathrm{NH}_{3}$, synthesized from $\mathrm{H}_{2}$ and $\mathrm{N}_{2}$, has been proposed as an alternative hydrogen storage material with high $\mathrm{H}$ density. Although in wide use, ammonia is both caustic and hazardous. When combined with $\mathrm{CO}_{2}$, a much safer precursor of ammonia - urea is formed, and the carbon dioxide is fixed at the same time. As energy medium, a critical factor is to release hydrogen for controlled delivery to presumably energy producing device. In this case, hydrogen is normally released thermally or through the use of hydrolysis or metal catalyst. There is also the possibility of directly retrieving energy from urea via direct urea fuel cell (DUFC) with high efficiency to complete the carbon and nitrogen recycle in figure 1. Besides, another main urea source is naturally the urea or urine rich wastewater, which is often leading to eutrophication ${ }^{5,6}$. Those urea/urine wastewaters can possibly be treated through oxidation reaction in DUFC to release nitrogen gas before their discharge into environments, or even turned to recycle water after further treatment.

DUFC is one of the key points to utilize urea in figure 1. In DUFC system, anode catalyst is a crucial component to catalyze urea oxidation reaction (UOR). Usually, noble metals such as $\mathrm{Pt}, \mathrm{Pd}$ and multi-metal catalysts based on them are used as anode catalysts in fuel cells with high activity ${ }^{7-11}$. However, noble metals will greatly increase the fuel cells cost and low activities toward UOR are observed in experiments ${ }^{12}$. Nickel, an inexpensive metal, shows high activity and stability, thus it is often attempted to adopt as anode catalyst in DUFC. Note that a large overpotential was reported (ca. $0.45 \mathrm{~V}$ vs. SHE), compared to the theoretical potential of UOR ( $-0.46 \mathrm{~V}$ vs. $\mathrm{SHE})^{13}$. It is reasonable that if we can reduce the overpotential, a better DUFC performance might be achieved.

Interestingly, cobalt was widely used as additive to form bimetal catalysts such as $\mathrm{NiCo}, \mathrm{PtCo}$ and $\mathrm{PdCo}^{14-17}$ to improve electro-activity of catalysts due to the particular electronic property of the bimetals. Among them, nickelcobalt bimetal has been intensively developed as efficient anode catalyst toward electrocatalytic oxidation of urea $^{18-20}$. Instead of power input for anodic oxidation, bimetallic catalysts could be a good choice for fuel cell ${ }^{17}$. Herein, it is feasible to apply nickel-cobalt bimetal for anode catalyst in DUFC to directly produce electricity. However, some researches drew opposite conclusions. Results demonstrated that the addition of Co could decrease the current densities of anodic peaks and even result in positive shifts of electro-oxidation onset potential ${ }^{21-23}$. It is believed that the Co contents and preparation methods are responsible for the different results of catalysts activities toward oxidation reactions. Accordingly, it is important to deeply survey the effect of Co addition on other metals. In this work, we focus on carbon supported Ni-Co bimetal catalyst aiming to enhance the activity toward UOR, and further improve the performance of DUFC. Herein, $\mathrm{NiCo} / \mathrm{C}$ catalysts are prepared via $\mathrm{NaBH}_{4}$ reduction method with different Co contents, and they are used as anode catalyst in DUFC to examine the activity. Besides, human urine, containing about $9.3 \mathrm{~g} \mathrm{~L}^{-1}$ urea $^{24}$, was possibly used as fuel in DUFC for its applicability study. Given the urea density of $1.335 \mathrm{~g} \mathrm{~mL}^{-1}$, the energy density of urine is $118 \mathrm{~kJ} \mathrm{~L}^{-1}$. It is a large 


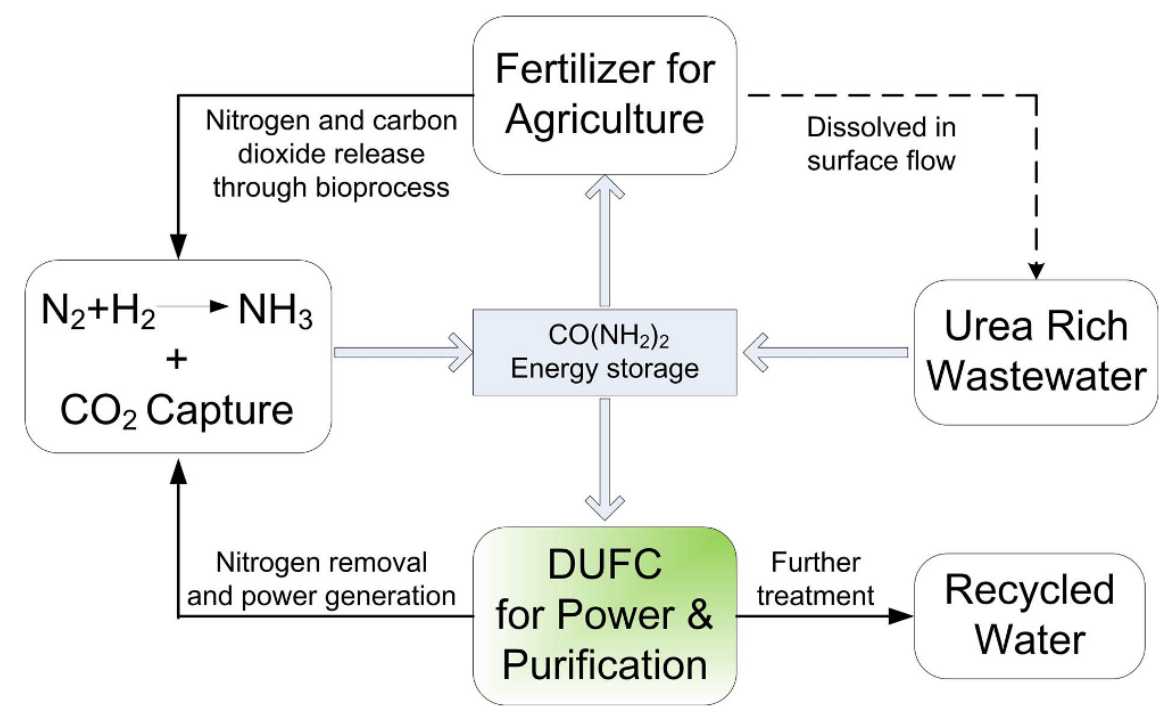

Figure $1 \mid$ Schematic of nitrogen and carbon dioxide recycle with urea as intermediate.

amount of energy considering the huge population of humans and animals all over the world. Thus we also test the cell performance using urine as fuel with $\mathrm{NiCo} / \mathrm{C}$ catalyst.

\section{Results}

SEM and TEM analyses were made in order to get information on the particle size and uniformity. Fig. 2(a) and (b) show the SEM images of $\mathrm{Ni} / \mathrm{C}(50 \mathrm{wt} \% \mathrm{Ni})$ and $\mathrm{NiCo} / \mathrm{C}(10 \mathrm{wt} \% \mathrm{Co}, 40 \mathrm{wt} \% \mathrm{Ni})$ respectively. The amount of $\mathrm{Ni}$ and $\mathrm{Co}$ supported on carbon black was roughly calculated by weighing $\mathrm{NiSO}_{4}$ and $\mathrm{CoCl}_{2}$ before the reduction process. In the SEM images, numerous $\mathrm{Ni}$ or NiCo particles were uniformly distributed on carbon though some agglomerations were observed. The secondary particle size of the prepared $\mathrm{Ni} / \mathrm{C}$ is about several $10^{-1} \mu \mathrm{m}$. Similarly, the $\mathrm{NiCo} / \mathrm{C}$ has secondary particle size of $0.2 \sim 1 \mu \mathrm{m}$, having a large specific area. TEM image of $\mathrm{Ni} / \mathrm{C}$ particle is shown in fig. 2(c). Ni/C nanospheres with primary particle size of $\sim 40 \mathrm{~nm}$ were prepared by $\mathrm{NaBH}_{4}$ reduction. $\mathrm{Ni} / \mathrm{C}$ nanoparticles were homogeneously and densely dispersed over the surface of carbon black. Fig. 2(d) demonstrates that most $\mathrm{NiCo} / \mathrm{C}$ nanoparticles have primary particle size of 30 to $40 \mathrm{~nm}$, though some much smaller particles with particle size of $\sim 5 \mathrm{~nm}$ were observed. It is supposed that the particle size of the catalysts were depended on the reduction condition (i.e. solution and $\mathrm{NaBH}_{4}$ concentration, the speed of adding $\mathrm{NaBH}_{4}$, temperature, $\mathrm{pH}$ ).

XRD patterns of $\mathrm{Ni} / \mathrm{C}$ and $\mathrm{NiCo} / \mathrm{C}$ were demonstrated in fig. 2(e). The blue line was the Ni/C XRD pattern. There is a strongest diffraction at $2 \theta \sim 45^{\circ}$ identified to be $\mathrm{Ni}(101)$ peak, indicating the formation of nickel. The peaks at $2 \theta \sim 60^{\circ}$ and $\sim 71^{\circ}$ signify nickel particle having a hexagonal structure. A nickel hydroxide peak is also observed at $2 \theta$ near $34^{\circ}$, revealing that some nickel was prepared in the form of $\mathrm{Ni}(\mathrm{OH})_{2}$. When cobalt was added (red line), the $\mathrm{Ni}(101)$ peak became much smaller, almost disappeared from the $\mathrm{NiCo} / \mathrm{C}$ pattern. On the contrary, the nickel hydroxide peak became larger at $2 \theta \sim 34^{\circ}$. It indicated that the incorporation of Co would promote much more nickel changing into the form of nickel hydroxide. Co (111) peak and $\mathrm{Co}(\mathrm{OH})_{2}$ peak were detected at $2 \theta \sim 44^{\circ}$ and $\sim 55^{\circ}$ respectively, indicating the formation of $\mathrm{NiCo} / \mathrm{C}$ catalyst. The peaks at $2 \theta \sim 24^{\circ}$ observed in both $\mathrm{Ni} / \mathrm{C}$ and $\mathrm{NiCo} / \mathrm{C}$ patterns were attributed to carbon black.

The surface composition of $\mathrm{NiCo} / \mathrm{C}$ was further confirmed by XPS measurement, and the results were shown in figs. $2(\mathrm{f})$ and $2(\mathrm{~g})$. In fig. 2(f), metallic $\mathrm{Ni}$ of $\mathrm{Ni}_{2 \mathrm{p} 1 / 2}$ and $\mathrm{Ni}_{2 \mathrm{p} 3 / 2}$ were detected at $870.2 \mathrm{eV}$ and $852.8 \mathrm{eV}$, respectively. In the $\mathrm{Ni}_{2 \mathrm{p} 3 / 2}$ spectrum, $\mathrm{NiO}$ peak appeared at $853.7 \mathrm{eV}$. The peaks of $854.9 \mathrm{eV}, 857.7 \mathrm{eV}$ and
$858.9 \mathrm{eV}$ are ascribed to the $\mathrm{Ni}(\mathrm{OH})_{2}$ peak, $\beta-\mathrm{NiOOH}$ peak and the $\mathrm{Ni}$ electron energy-loss peak, respectively ${ }^{25,26}$. The $\mathrm{Ni}(\mathrm{OH})_{2}$ and $\beta-\mathrm{NiOOH}$ together account for about $29.4 \%$ of the total $\mathrm{Ni}$ element on the surface, a result from XPS peak area. It has also been found that metallic $\mathrm{Co}$ and $\mathrm{Co}(\mathrm{OH})_{2}$ were on the surface of $\mathrm{NiCo} / \mathrm{C}$ from the $\mathrm{Co}_{2 \mathrm{p}}$ XPS spectra in fig. $2(\mathrm{~g})$. The main peaks at $778.1 \mathrm{eV}$ and $794.0 \mathrm{eV}$ were attributed to the metallic $\mathrm{Co}$ of $\mathrm{Co}_{2 \mathrm{p} 3 / 2}$ and $\mathrm{Co}_{2 \mathrm{p} 1 / 2}$. The $\mathrm{Co}_{2 \mathrm{p} 3 / 2}$ spectrum contains a $\mathrm{Co}(\mathrm{OH})_{2}$ peak at $780.4 \mathrm{eV}$. The Co element constituted about $26.6 \%$ of the total $\mathrm{Ni}$ and Co elements on the surface.

It is expected that the addition of Co would enhance the Ni activity toward UOR, thus improve DUFC performance. Fig. 2(h) demonstrated the DUFC performance using Ni/C (Cell A) or NiCo/C (Cell $\mathrm{B}$ ) as anode catalyst. Both cells used $0.33 \mathrm{M}$ urea as fuels and humidification oxygen as electrons acceptor. Cell A achieved a maximum power density $\left(\mathrm{P}_{\max }\right)$ of $1.4 \mathrm{~mW} \mathrm{~cm}^{-2}$ with an open circuit voltage (OCV) of 0.57 V. In comparison with Cell A, Cell B achieved a larger maximum power density of $2.0 \mathrm{~mW} \mathrm{~cm}{ }^{-2}$ with an OCV of $0.64 \mathrm{~V}$. The $\mathrm{P}_{\max }$ of Cell B was 1.43 times that of Cell A. Besides, a more significant decline of cell voltage was observed in Cell A, which was attributed to the electrochemical polarization. It indicated that the $\mathrm{NiCo} / \mathrm{C}$ catalyst with $10 \mathrm{wt} \%$ Co content could perform better than the $\mathrm{Ni} / \mathrm{C}$ catalyst.

\section{Discussion}

XRD and XPS measurements demonstrated that nickel hydroxide was synthesized when the Co was incorporated. The increased nickel hydroxide will lead to the more active sites exposed for $\mathrm{UOR}^{27-29}$, possibly one reason for DUFC improvement. In order to further explain the reason why the addition of cobalt would influence the catalytic activity, CVs of $0.33 \mathrm{M}$ urea in $1 \mathrm{M} \mathrm{KOH}$ were tested. All the catalysts have the same metal weight percent of $50 \%$ in order to compare the catalysts activity under the same metallic content, i.e. $\mathrm{NiCo}$ or $\mathrm{Ni}$ were mixed with carbon at a 5/5 mass ratio. The subscripts of $\mathrm{Ni}$ and $\mathrm{Co}$ represent the mass ratio of Ni/Co. Fig. 3(a) shows a pair of reduction and oxidation peaks between 0.25 to $0.55 \mathrm{~V} v s$. MMO. These peaks are regarded as the reversible conversion of $\mathrm{Ni}(\mathrm{OH})_{2}\left(\mathrm{Ni}^{2+}\right) \leftrightarrow \mathrm{NiOOH}\left(\mathrm{Ni}^{3+}\right)$ in alkaline system ${ }^{19}$. A significant increase on current with the onset potential ca. $0.44 \mathrm{~V} v s$. MMO was revealed when urea was added. The onset potential of UOR is the same as the potential where $\mathrm{NiOOH}\left(\mathrm{Ni}^{3+}\right)$ is formed. This phenomenon demonstrates that urea is possibly electro-oxidized on catalytic $\mathrm{NiOOH}\left(\mathrm{Ni}^{3+}\right)$. Thus, it is reasonable that the onset potential of UOR will decrease if we can generate $\mathrm{NiOOH}\left(\mathrm{Ni}^{3+}\right)$ at a 

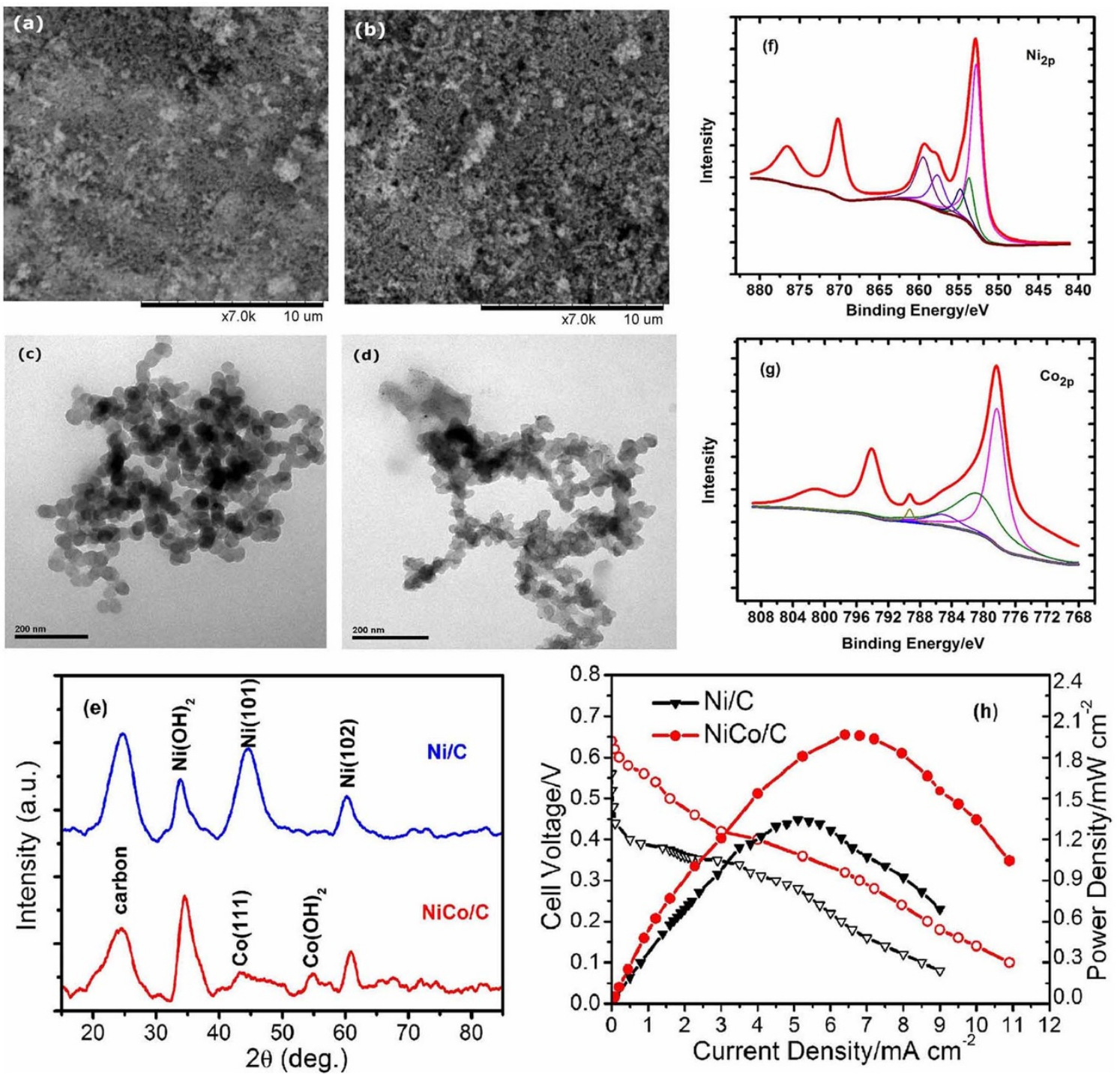

Figure 2 Characterizations of catalysts and DUFC performance. SEM images of (a) Ni/C and (b) NiCo/C. TEM images of (c) Ni/C and (d) NiCo/C. (e) XRD patterns of $\mathrm{Ni} / \mathrm{C}$ (blue) and $\mathrm{NiCo} / \mathrm{C}$ (red). XPS spectra of $\mathrm{NiCo} / \mathrm{C}$ for $(\mathrm{f}) \mathrm{Ni}_{2 \mathrm{p}}$ and $\left(\mathrm{g}\right.$ ) $\mathrm{Co}_{2 \mathrm{p}}$. (h) Polarization and power density curves of DUFC at $60^{\circ} \mathrm{C}$ with $0.33 \mathrm{M}$ urea as fuel and humidification oxygen as electrons acceptor using $\mathrm{Ni} / \mathrm{C}$ or $\mathrm{NiCo} / \mathrm{C}$ as anode catalyst, $\mathrm{Pt} / \mathrm{C}$ as cathode catalyst.

smaller potential. Fig. 3(b) demonstrates the onset potential of UOR shifts left to ca. $0.38 \mathrm{~V}$ vs. MMO, showing a decline of $60 \mathrm{mV}$ in the overpotential of UOR. According to above discussion, the decline of UOR onset potential is due to the smaller potential where $\mathrm{NiOOH}$ $\left(\mathrm{Ni}^{3+}\right)$ is formed. As a preferable overpotential is observed in $\mathrm{CV}$ tests, the $\mathrm{Ni}_{4} \mathrm{Co}_{1} / \mathrm{C}$ catalyst may improve the electrochemical polarization in DUFC, which is in accordance with the results in fig. 2(h). If the Co content is increased, forming $\mathrm{Ni}_{3} \mathrm{Co}_{2} / \mathrm{C}$ in fig. $3(\mathrm{c})$, the onset potential decreases further to ca. $0.31 \mathrm{~V}$ vs. MMO, $130 \mathrm{mV}$ less compared to $\mathrm{Ni} / \mathrm{C}$. It can be explained that $\mathrm{Ni}$ reaches a higher oxidation state during the UOR and promotes the electrons transfer when Co is doped ${ }^{30,31}$. This property can be confirmed by electrical conductivity $(\sigma)$ tests at $20^{\circ} \mathrm{C}$. Fig. (3f) shows that the electrical conductivity of $\mathrm{Ni} / \mathrm{C}$ is $\sim 0.131 \mathrm{~S} \mathrm{~cm}^{-1}$. It increases as the amount of Co addition, reaching $\sim 0.168 \mathrm{~S} \mathrm{~cm}^{-1}$ of $\mathrm{Ni}_{4} \mathrm{Co}_{1} / \mathrm{C}$ and $\sim 0.201 \mathrm{~S}$ $\mathrm{cm}^{-1}$ of $\mathrm{Ni}_{3} \mathrm{Co}_{2} / \mathrm{C}$, respectively. This phenomenon is in accordance with catalytic activity improvement of $\mathrm{NiCo} / \mathrm{C}$ bimetal catalysts. However, as the Co contents continue to increase, although the $\sigma$ still becomes larger, the onset potential will shift to positive direction. The onset potential of $\mathrm{Ni}_{2} \mathrm{Co}_{3} / \mathrm{C}$ is $0.38 \mathrm{~V}$ vs. MMO shown in fig. 3(d) and it shifts to $0.41 \mathrm{~V}$ when using $\mathrm{Ni}_{1} \mathrm{Co}_{4} / \mathrm{C}$ as catalyst shown in fig. 3(e). The onset potentials using $\mathrm{NiCo} / \mathrm{C}$ catalysts are summarized in fig. 3(f). Briefly, the incorporation of Co will reduce the onset potential, and the most negative one is achieved when using $\mathrm{Ni}_{3} \mathrm{Co}_{2} / \mathrm{C}$. Further increase the Co content will lead to larger onset potential. Besides, the electro-oxidation current of urea is decreasing as the Co content in $\mathrm{NiCo} / \mathrm{C}$ increasing. The main reason may be that cobalt is inactive for UOR, which decreases the exposed nickel active sites, thus hinder the UOR ${ }^{19}$. The addition of Co had advantages (reducing onset potential, ROP) as well as disadvantages (reducing electro-oxidation potential, REP), so it is important to seek a balance between the two effects in order to achieve the best catalyst activity. Based on this, we suppose the DUFC performance is depended on the positive influence of ROP and negative influence of REP.

The activity of $\mathrm{NiCo} / \mathrm{C}$ toward UOR is further evaluated in DUFC. Fig. 4(a) shows the DUFC has the largest electricity output when using $\mathrm{NiCo} / \mathrm{C}$ catalyst with $10 \% \mathrm{Co}$. The cell performance will decline when the Co contents exceeded 10\%. Although the most negative onset potential in $\mathrm{CV}$ tests was achieved when using $\mathrm{Ni}_{3} \mathrm{Co}_{2} / \mathrm{C}$ catalyst, the optimal $\mathrm{P}_{\max }$ of DUFC was observed using $\mathrm{Ni}_{4} \mathrm{Co}_{1} / \mathrm{C}$ as anode catalyst. That was because the electro-oxidation current in CVs dropped rapidly when the Co content exceeded 10\% due to the Co inactivation toward UOR. The negative influence of REP was larger than positive influence of ROP. Fig. 4(b) outlined the 

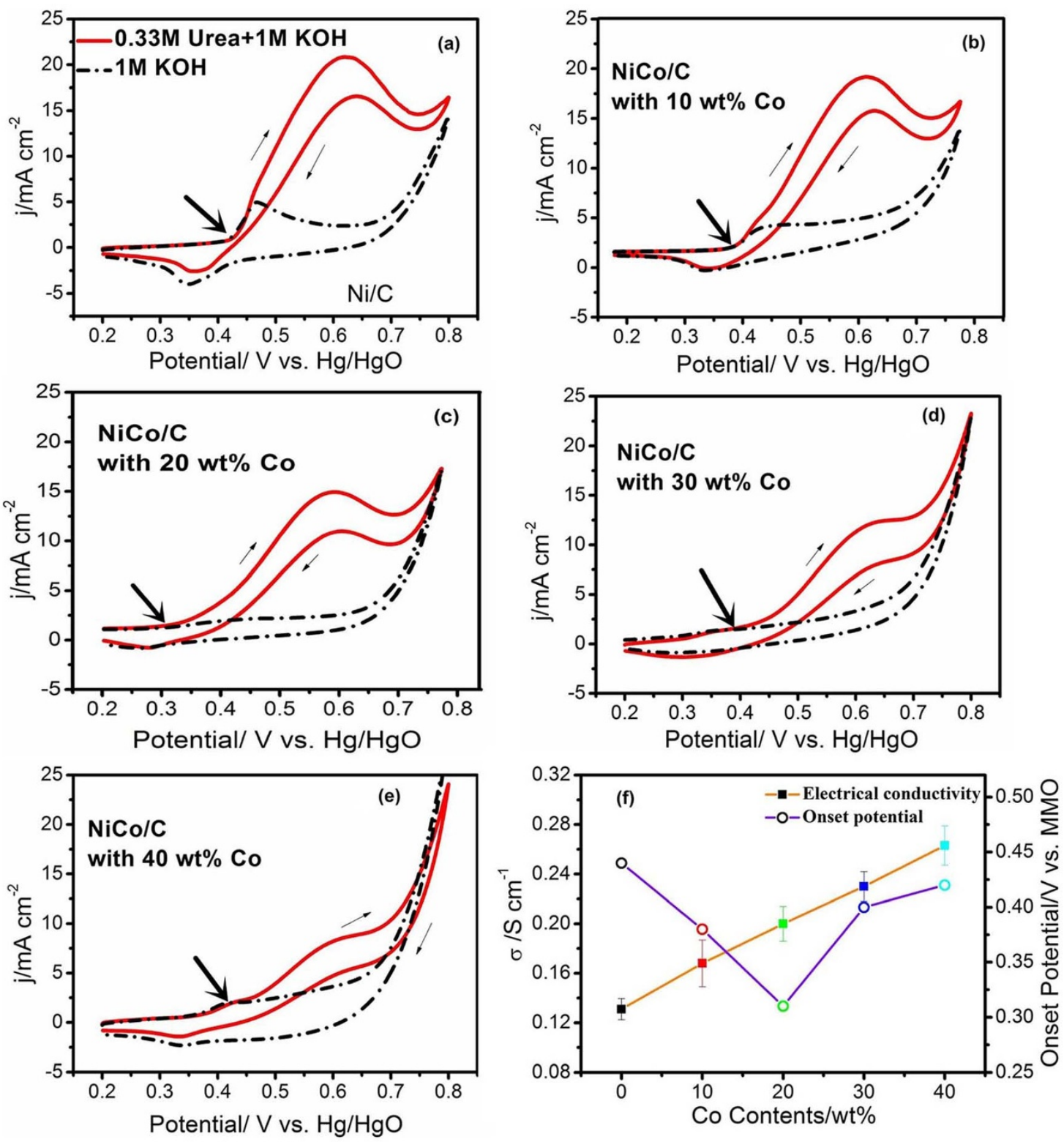

Figure 3 Cyclic voltammograms (CVs). The Cvs were measured in $1 \mathrm{M} \mathrm{KOH}$ or $0.33 \mathrm{M}$ urea $+1 \mathrm{M} \mathrm{KOH}$ at $20^{\circ} \mathrm{C}$. The CVs were conducted on (a) Ni/ C, (b) $\mathrm{Ni}_{4} \mathrm{Co}_{1} / \mathrm{C}$, (c) $\mathrm{Ni}_{3} \mathrm{Co}_{2} / \mathrm{C}$, (d) $\mathrm{Ni}_{2} \mathrm{Co}_{3} / \mathrm{C}$ and (e) $\mathrm{Ni}_{1} \mathrm{Co}_{4} / \mathrm{C}$ coated GCE at a scan rate of $50 \mathrm{mV} \mathrm{s}^{-1}$. (f) Electrical conductivity of samples (data are an average of three runs; error bars indicate the standard deviation) and summary of onset potentials.

OCV and $\mathrm{P}_{\max }$ of DUFC using $\mathrm{NiCo} / \mathrm{C}$ as anode catalyst with various Co contents. The $\mathrm{P}_{\max }$ continued to decrease as Co content increasing from $20 \%$ to $40 \%$. Results showed the $\mathrm{P}_{\max }$ of $\mathrm{Ni}_{2} \mathrm{Co}_{3} / \mathrm{C}$ was similar to that of $\mathrm{Ni} / \mathrm{C}$, and the $\mathrm{P}_{\max }$ of $\mathrm{Ni}_{1} \mathrm{Co}_{4} / \mathrm{C}$ was a little smaller than that of $\mathrm{Ni} / \mathrm{C}$. This was reasonable because the UOR over-potential turned to became larger after Co content exceeding $20 \%$, and thus the positive influence of ROP got smaller, even disappeared. However the negative influence of REP would still become larger, thus doping too much of Co would not have better effect on the $\mathrm{P}_{\max }$ of DUFC. Note that the highest OCV of DUFC was achieved when using $\mathrm{Ni}_{3} \mathrm{Co}_{2} / \mathrm{C}$ as anode catalyst. This was in accordance with the $\mathrm{ROP}$ effect in $\mathrm{CV}$ tests, indicating that a smaller over-potential was to the benefit of a higher OCV due to the less polarisation loss.

Higher temperature is beneficial to the catalytic activity of $\mathrm{NiCo} /$ $\mathrm{C}$, and it will enhance the reaction kinetics of urea hydrolysis and UOR. Fig 4(c) shows the maximum power density decrease to $1.6 \mathrm{~mW} \mathrm{~cm} \mathrm{~cm}^{-2}$ at $40^{\circ} \mathrm{C}$ and $1.4 \mathrm{~mW} \mathrm{~cm}^{-2}$ at $20^{\circ} \mathrm{C}$, respectively. Higher drop in voltage with current density is found at lower voltage (after $0.4 \mathrm{~V}$ ) at $20^{\circ} \mathrm{C}$ and $40^{\circ} \mathrm{C}$ than that at $60^{\circ} \mathrm{C}$, indicating the lower concentration or diffusion resistance at high temperature. However, ammonia gas will be generated significantly at high temperature (above $60^{\circ} \mathrm{C}$ ) due to the urea hydrolysis. This will cause the fuels loss and gas leakage.

Fig. 4(d) shows the DUFC performance using human urine as fuels with $\mathrm{NiCo} / \mathrm{C}$ anode catalyst. A maximum power density of $0.06 \mathrm{~mW} \mathrm{~cm}^{-2}$ is achieved with an $\mathrm{OCV}$ of $0.3 \mathrm{~V}$ at $20^{\circ} \mathrm{C}$. Higher temperature will improve the cell performance owing to the better catalytic activity of the electrode and reaction kinetics. The maximum power density increases to $0.08 \mathrm{~mW} \mathrm{~cm}^{-2}$ at $40^{\circ} \mathrm{C}$ and $0.2 \mathrm{~mW} \mathrm{\textrm {cm } ^ { - 2 }}$ at $60^{\circ} \mathrm{C}$, when the urine sample containing about $0.1 \mathrm{M}$ urea was applied. Compared to the fuel cell using $0.1 \mathrm{M}$ urea as fuel (with an OCV of $0.45 \mathrm{~V}$ and a maximum power density of $\sim 0.3 \mathrm{~mW} \mathrm{~cm}^{-2}$ ), the cell performance of urine fuel cell (with an OCV of $0.38 \mathrm{~V}$ and a maximum power density of $\sim 0.2 \mathrm{~mW} \mathrm{~cm}^{-2}$ ) was insignificantly different at $60^{\circ} \mathrm{C}$. Urine is a main contaminant in the municipal wastewater, and it is also an ideal energy resource 

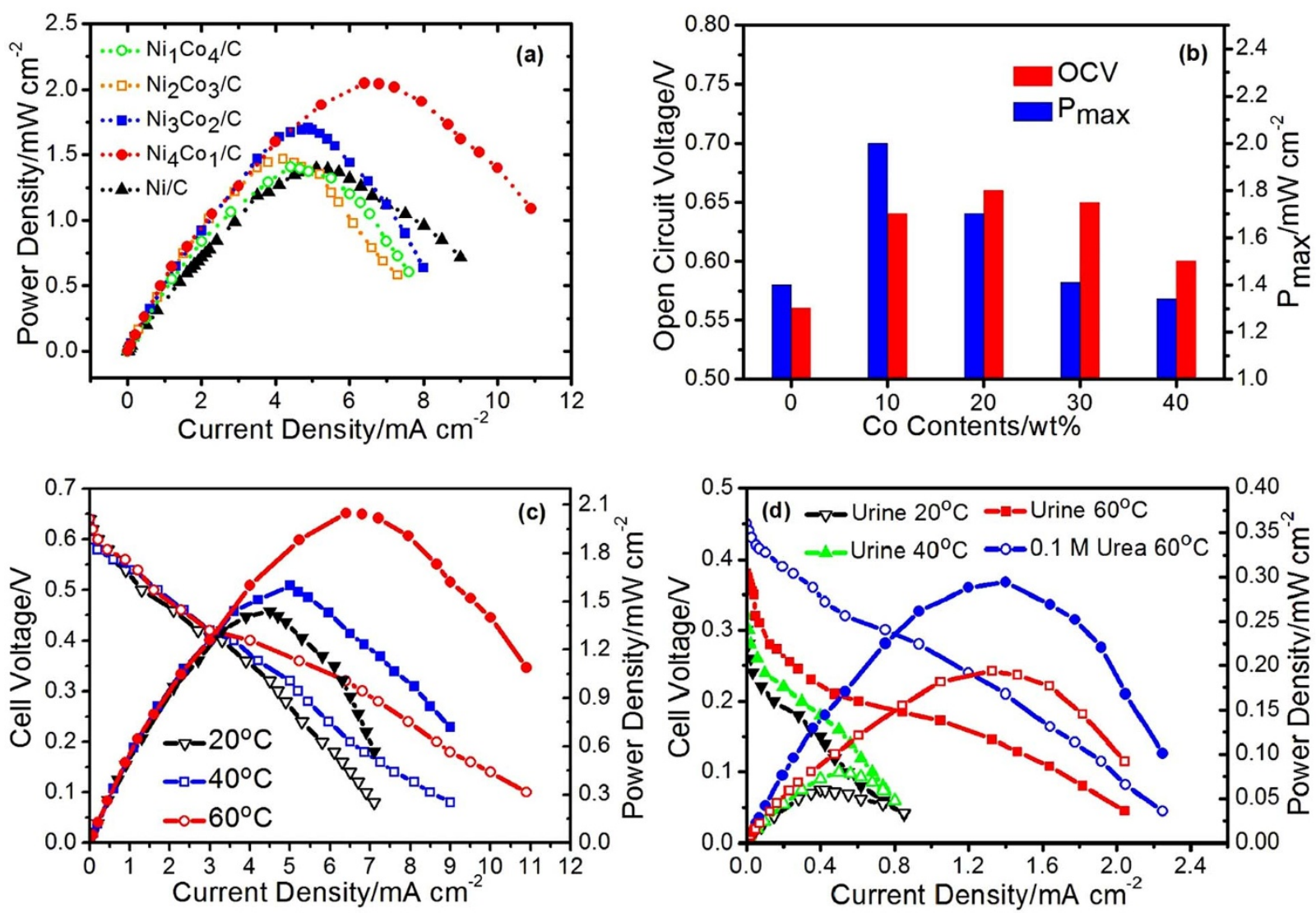

Figure $4 \mid$ DUFC performance. (a) Power density curves of DUFC using NiCo/C catalysts with different Co contents. (b) The effects of catalysts on DUFC maximum power density and open circuit voltage. (c) DUFC performance using $0.33 \mathrm{M}$ urea at $20,40,60^{\circ} \mathrm{C}$ with $\mathrm{Ni}_{4} \mathrm{Co}_{1} / \mathrm{C}$ as anode catalyst and $(\mathrm{d})$ Human urine was used as fuel in DUFC at $20^{\circ} \mathrm{C}, 40^{\circ} \mathrm{C}$ and $60^{\circ} \mathrm{C}$, respectively, in comparison with $0.1 \mathrm{M}$ urea at $60^{\circ} \mathrm{C}$.

coming from human or animal, which is very common and huge. Direct urine fuel cell can possibly be applied to purify urine through urea oxidation reaction with electricity generated at the same time, especially in manned spaceship and submarine as a part of life support system. Further related researches such as urine-tolerant separator and reaction mechanisms need to be carried out to make it an alternative to produce electricity or even treat wastewater.

\section{Methods}

Preparation of $\mathrm{NiCo} / \mathrm{C}$ catalysts and electrodes. Nickel-cobalt catalysts were prepared by the $\mathrm{NaBH}_{4}$ reduction method. Typically, $\mathrm{NiSO}_{4} \cdot 6 \mathrm{H}_{2} \mathrm{O}, \mathrm{CoCl}_{2} \cdot 6 \mathrm{H}_{2} \mathrm{O}$ and citric acid were dissolved into $250 \mathrm{~mL}$ deionized water in a flask with specific weight ratio. The solution was treated by 15 minutes aeration of nitrogen gas. Then fresh $\mathrm{NaBH}_{4}$ solution (4 wt\%) was added dropwise into the mixed aqueous solution with violently stirring. After stirring for 3 hours, black carbon (Carbon Vulcan XC-72R) was added into the bottle. Three hours later, the mixture was filtered and washed with deionised water for $3-5$ times. The precipitate was dried in vacuum oven at $50^{\circ} \mathrm{C}$ overnight. Five kinds of catalysts were prepared with Co contents of $0,10,20,30$, $40 \mathrm{wt} \%$ respectively, and the carbon weight percent was $50 \%$ in all catalyst. Accordingly we call them $\mathrm{Ni} / \mathrm{C}, \mathrm{Ni}_{4} \mathrm{Co}_{1} / \mathrm{C}, \mathrm{Ni}_{3} \mathrm{Co}_{2} / \mathrm{C}, \mathrm{Ni}_{2} \mathrm{Co}_{3} / \mathrm{C}$ and $\mathrm{Ni}_{1} \mathrm{Co}_{4} / \mathrm{C}$ respectively.

Carbon cloth (Hesen, Shanghai, China) was immersed in 30\% PTFE solution (Hesen, Shanghai, China) for $10 \mathrm{~min}$, and then heated at $370^{\circ} \mathrm{C}$ for $25 \mathrm{~min}$ as pretreatment. Catalysts were mixed with isopropanol, water and 5\% Nafion (DE520, DuPont, USA) in ultrasonic bath for 30 minutes to obtain catalyst inks. They were coated on the carbon cloth using a paintbrush with the NiCo loading of $\sim 10 \mathrm{mg}$ $\mathrm{cm}^{-2}$. Then the electrodes coated catalysts were dried in air for at least $24 \mathrm{~h}$ prior to use. The geometric area of all electrodes was $2.0 \mathrm{~cm}^{-2}$. Pt/C coated carbon cloth was used as cathode with a Pt loading of $\sim 1.0 \mathrm{mg} \mathrm{cm}^{-2}$.

Characterizations of catalysts. X-ray diffraction (XRD) measurements were performed by using Shimadzu XRD-6000 equipped with a $\mathrm{Cu}-\mathrm{K} \alpha$ radiation source $\left(\lambda=1.54056 \AA\right.$ ) and operating at $40 \mathrm{kV}$ and $40 \mathrm{~mA}$. The data of XRD between $15^{\circ}$ and $85^{\circ} 2 \theta$ angular regions was collected.

Surface composition of the bimetal catalyst was inferred from X-ray photoelectron spectroscopy (XPS), using an ESCALAB_250Xi X-ray photoelectron spectrometer with $\mathrm{Al} \mathrm{K \alpha} \mathrm{X-ray} \mathrm{as} \mathrm{the} \mathrm{excitation} \mathrm{source.} \mathrm{The} \mathrm{sample} \mathrm{was} \mathrm{pressed} \mathrm{to} \mathrm{an} 8 \mathrm{~mm}$ diameter disc before test. The charging effect of the sample was corrected by standard carbon $(\mathrm{C} 1 \mathrm{~s}=284.6 \mathrm{eV})$.

The obtained $\mathrm{Ni} / \mathrm{C}$ and $\mathrm{NiCo} / \mathrm{C}$ electrocatalysts were characterized by transmission electron microscopy (TEM, JEOL JEM-1230) at a voltage of $120 \mathrm{kv}$. The sample was dispersed in alcohol solvent by ultrasonic action and dropped onto a carboncoated copper grid. Scanning Electron Microscopes (SEM) were conducted by Hitachi TM1000.

Electrochemical measurements were conducted in $1 \mathrm{M} \mathrm{KOH}$ or $0.33 \mathrm{M}$ urea $+1 \mathrm{M} \mathrm{KOH}$ using glass carbon electrode (GCE) with $3 \mathrm{~mm}$ diameter connected to an electrochemical workstation (CHI 660D, Shanghai Chenhua). Typically, $5 \mathrm{mg}$ catalyst was mixed with $0.1 \mathrm{~mL}$ Nafion and $0.4 \mathrm{~mL}$ water in ultrasonic bath for 30 minutes to get catalyst ink. Then $6 \mu \mathrm{L}$ of ink was dropped onto GCE ( $3 \mathrm{~mm}$ diameter) and dry at room temperature. A platinum foil $\left(0.3 \mathrm{~cm}^{2}\right)$ was used as the counter electrode. $\mathrm{An} \mathrm{Hg} / \mathrm{HgO}$ electrode (MMO) was used as reference electrode. The electrolyte was bubbled by nitrogen gas for 20 minutes before the tests. Cyclic voltammograms (CV) were performed from $0.2 \mathrm{~V}$ to $0.8 \mathrm{~V} v s$. MMO at a scan rate of $50 \mathrm{mV}$ $\mathrm{s}^{-1}$, and all results were collected after scanning at least for 5 times.

Electrical conductivities $(\sigma)$ were measured at room temperature by a digital fourprobe measuring instrument (RTS-8, 4 PROBES TECH, CHINA) controlled by a computer. The catalysts were compressed into sheets before measurement.

Fuel cell testing and analysis. Anion exchange membrane (AEM, AMI-7001, AMFOR INC.) is used as polymer electrolyte to make membrane electrode assembly $(M E A)^{3,4}$, both the anode and cathode have the same active area of $2.0 \times 2.0 \mathrm{~cm}$. Stainless steel plates with serpentine flow channels are used as the flow field plates and current collectors both at the cathode and anode. At the anodes, $0.33 \mathrm{M}$ urea or urine is fed into flow channel as fuels at a flow rate of $3.0 \mathrm{~mL} \mathrm{~min}^{-1}$ by peristaltic pumps, and they are kept in a constant temperature water bath. At the cathodes, humidification oxygen is used as electrons acceptor. A data acquisition system (PISO813 , ICP DAS) is used to measure the fuel cell performance. RP-HPLC (FL2200) was applied to the determination of urea in human urine separating by Waters Atlantis T3. The concentration of urea was determined by diode array detector at the wavelength of $195 \mathrm{~nm}$.

1. Meessen, J. H. [Urea]. Ullmann's Encyclopedia of Industrial Chemistry. (Wiley$\mathrm{VCH}$, Germany, 2010). 
2. Shriver, D. \& Atkins, P. Inorganic Chemistry. (W. H. Freeman, the United States, 2010).

3. Lan, R. \& Tao, S. Preparation of nano-sized nickel as anode catalyst for direct urea and urine fuel cells. J. Power Sources 196, 5021-5026 (2011).

4. Lan, R., Tao, S. \& Irvine, J. T. S. A direct urea fuel cell - power from fertiliser and waste. Energy Environ. Sci. 3, 438-441 (2010).

5. Hamonts, K. et al. Influence of soil bulk density and matric potential on microbial dynamics, inorganic $\mathrm{N}$ transformations, $\mathrm{N}_{2} \mathrm{O}$ and $\mathrm{N}_{2}$ fluxes following urea deposition. Soil Biol. Biochem. 65, 1-11 (2013).

6. Chang, J. J., Wu, S. Q., Dai, Y. R., Liang, W. \& Wu, Z. B. Nitrogen removal from nitrate-laden wastewater by integrated vertical-flow constructed wetland systems. Ecol. Eng. 58, 192-201 (2013).

7. Choi, I. D., Lee, H., Shim, Y. B. \& Lee, D. A one-Step continuous synthesis of carbon-supported Pt catalysts using a flame for the preparation of the fuel electrode. Langmuir 26, 11212-11216 (2010).

8. Dutta, A. \& Datta, J. Outstanding catalyst performance of PdAuNi nanoparticles for the anodic reaction in an alkaline direct ethanol (with anion-exchange membrane) fuel cell. J. Phys. Chem. C 116, 25677-25688 (2012).

9. $\mathrm{Fu}, \mathrm{Q}$. et al. Interface-confined ferrous centers for catalytic oxidation. Science 328, 1141-1144 (2010).

10. Sun, S. et al. Single-atom catalysis using Pt/graphene achieved through atomic layer deposition. Sci. Rep. 3, 1775 (2013).

11. Hwang, S. J. et al. Supported core@shell electrocatalysts for fuel cells: close encounter withreality. Sci. Rep. 3, 1309 (2013).

12. Boggs, B. K., King, R. L. \& Botte, G. G. Urea electrolysis: direct hydrogen production from urine. Chem. Commun. 32, 4859-4861 (2009).

13. King, R. L. \& Botte, G. G. Hydrogen production via urea electrolysis using a gel electrolyte. J. Power Sources 196, 2773-2778 (2011)

14. Tang, Y. et al. Electro-catalytic performance of PdCo bimetallic hollow nanospheres for the oxidation of formic acid. J. Solid State Electrochem. 14, 2077-2082 (2010)

15. Wang, X. \& Xia, Y. Electrocatalytic performance of PdCo-C catalyst for formic acid oxidation. Electrochem Commun. 10, 1644-1646 (2008).

16. Huang, H., Fan, Y. \& Wang, X. Low-defect multi-walled carbon nanotubes supported PtCo alloy nanoparticles with remarkable performance for electrooxidation of methanol. Electrochim. Acta 80, 118-125 (2012).

17. Wang, Z. et al. High electrocatalytic activity of non-noble Ni-Co/graphene catalyst for direct ethanol fuel cells. J. Solid State Electrochem. 17, 99-107 (2013).

18. Vidotti, M. et al. Electrocatalytic oxidation of urea by nanostructured nickel/ cobalt hydroxide electrodes. Electrochim. Acta 53, 4030-4034 (2008).

19. Yan, W., Wang, D. \& Botte, G. G. Nickel and cobalt bimetallic hydroxide catalysts for urea electro-oxidation. Electrochim. Acta 61, 25-30 (2012).

20. Ding, R. et al. Facile synthesis of mesoporous spinel $\mathrm{NiCo}_{2} \mathrm{O}_{4}$ nanostructures as highly efficient electrocatalysts for urea electro-oxidation. Nanoscale 6 , 1369-1376 (2014)

21. Hernandez-Fernandez, P. et al. Effect of Co in the efficiency of the methanol electrooxidation reaction on carbon supported Pt. J. Power Sources 195, 7959-7967 (2010).

22. Gojkovic, S. L. Electrochemical oxidation of methanol on Pt3Co bulk alloy. J. Serb. Chem. Soc. 68, 859-870 (2003).
23. Salgado, J. R. C., Antolini, E. \& Gonzalez, E. R. Carbon supported Pt-Co alloys as methanol-resistant oxygen-reduction electrocatalysts for direct methanol fuel cells. Appl. Catal. B 57, 283-290 (2005).

24. Putnam, D. F. Composition and Concentrative Properties of Human Urine. (NASA Contractor Report, the United States, 1971).

25. Dai, W.-L., Qiao, M.-H. \& Deng, J.-F. XPS studies on a novel amorphous Ni-CoW-B alloy powder. Appl. Surf. Sci. 120, 119-124 (1997).

26. Biesinger, M. C., Payne, B. P., Grosvenor, A. P., Lau, L. W. M., Gerson, A. R. \& Smart, R. St. C. Resolving surface chemical states in XPS analysis of first row transition metals, oxides and hydroxides: $\mathrm{Cr}, \mathrm{Mn}, \mathrm{Fe}, \mathrm{Co}$ and Ni. Appl. Surf. Sci. 257, 2717-2730 (2011)

27. Vidotti, M., Silva, M. R., Salvador, R. P., Córdoba de Torresi, S. I. \& Dall'Antonia, L. H. Electrocatalytic oxidation of urea by nanostructured nickel/cobalt hydroxide electrodes. Electrochim. Acta 53, 4030-4034 (2008).

28. Kim, J. W. \& Park, S. M. In situ XANES studies of electrodeposited nickel oxide films with metal additives for the electro-oxidation of ethanol. J. Electrochem. Soc. 150, E560-E566 (2003).

29. Córdoba de Torresi, S. I., Provazi, K., Malta, M. \& Torresi, R. M. Effect of additives in the stabilization of the $\alpha$ Phase of $\mathrm{Ni}(\mathrm{OH})_{2}$ electrodes. J. Electrochem. Soc. 148, A1179-A1184 (2001).

30. Armstrong, R. D. \& Charles, E. A. Some effects of cobalt hydroxide upon the electrochemical behaviour of nickel hydroxide electrodes. J. Power Sources 25, 89-97 (1989).

31. Armstrong, R. D., Briggs, G. W. D. \& Charles, E. A. Some effects of the addition of cobalt to the nickel hydroxide electrode. J. Appl. Electrochem. 18, 215-219 (1988).

\section{Acknowledgments}

The authors are grateful for the financial support of NSFC (Grant No. 21073161,21173188).

\section{Author contributions}

W.X. proposed the concept. Z.W. directed the research. W.X., H.Z. and Z.W. designed the experiments. W.X., H.Z. and G.L. carried out the experiments. W.X. and H.Z. wrote the main manuscript text and prepared figures. All authors reviewed the manuscript.

\section{Additional information}

Competing financial interests: The authors declare no competing financial interests.

How to cite this article: Xu, W., Zhang, H., Li, G. \& Wu, Z. Nickel-cobalt bimetallic anode catalysts for direct urea fuel cell. Sci. Rep. 4, 5863; DOI:10.1038/srep05863 (2014).

This work is licensed under a Creative Commons Attribution-NonCommercialNoDerivs 4.0 International License. The images or other third party material in this article are included in the article's Creative Commons license, unless indicated otherwise in the credit line; if the material is not included under the Creative Commons license, users will need to obtain permission from the license holder in order to reproduce the material. To view a copy of this license, visit http:// creativecommons.org/licenses/by-nc-nd/4.0/ 